Matarirano, O. et al. Students' Responses to Multi-Modal Emergency Remote Learning During COVID-19 in a South African Higher Institution

\title{
Students' Responses to Multi-Modal Emergency Remote Learning During COVID-19 in a South African Higher Institution
}

\author{
Obert Matarirano* ${ }^{*}$, Onke Gqokonqana ${ }^{1}$ \& Abor Yeboah $^{1}$ \\ *Corresponding Author: omatarirano@wsu.ac.za \\ 1. Walter Sisulu University, Department of Accounting and Finance, South Africa \\ Received : 2021-06-13 \\ Revised : 2021-07-19 \\ Accepted : 2021-08-30 \\ d \\ 10.46303/ressat.2021.19
}

\begin{abstract}
How to cite this paper: Matarirano, O., Gqokonqana, O. \& Yeboah, A. (2021). Students' Responses to Multi-Modal Emergency Remote Learning During COVID-19 in a South African Higher Institution. Research in Social Sciences and Technology, 6(2), $199-218$. https://doi.org/10.46303/ressat.2021.19

This is an Open Access article distributed under the terms of the Creative Commons Attribution 4.0 International license (https://creativecommons.org/licenses/by/4.0/).
\end{abstract}

\begin{abstract}
COVID-19 pandemic forced several higher education institutions (HEI) to operate remotely. Emergency remote teaching, using synchronous and asynchronous instruction, was adopted by several HEls. The experiences of students with remote teaching and learning in certain situations are not fully understood, thus need to be explored. This study explored the experiences of students with the emergency remote teaching and learning practices adopted at a selected HEl in South Africa. A cross-sectional and self-administered survey was used to gather data from 243 conveniently sampled returning students within the Department of Accounting and Finance. Descriptive statistics were used to make sense of the collected data. The study found that students preferred a face-to-face approach to learning to remote learning. The respondents underscored insufficient data, unstable network connection, unconducive home environments and loneliness as deterrents to effective remote learning. Despite these negative experiences, students appreciated the flexibility and convenience of recorded video lectures and acknowledged the compassion and support of lecturers during remote learning. An understanding of the experiences of students during remote learning provides a basis for future teaching plans, which would improve students' learning experiences. In its current format and students living in their home environments, remote learning greatly diminishes the chances of success for most students. Lecturers need to be compassionate and considerate of student's struggles in their plans for remote teaching and learning as well as online learning.
\end{abstract}

Keywords: Emergency remote teaching and learning; interaction; remote learning; online learning; synchronous instruction; asynchronous instruction. 
Matarirano, O. et al. Students' Responses to Multi-Modal Emergency Remote Learning During COVID-19 in a South African Higher Institution

\section{Introduction}

COVID-19 pandemic has caused several governments to take drastic measures to curb its effects. One such measure was restricting movements by imposing lockdowns where educational institutions, among others, were forced to close. South African government announced a national lockdown on the 23rd of March 2020, which was to take effect on the $27^{\text {th }}$ of March 2021 (South African Government News Agency, 2020). With universities closed, the only way of saving the academic year was through the adoption of emergency remote teaching and learning [ERTL] (Czerniewicz et al., 2020; Jena, 2020) that was facilitated by advancements in technology (Ewing \& Cooper, 2021).

ERTL is a temporary move from face-to-face and blended teaching to a remote approach as a response to a crisis (Hodges, Moore, Lockee, Trust \& Bond, 2020). Primarily, it is facilitated by technology in higher education (HE) as several studies have showcased (Ferri et al., 2020; Mohmmed et al., 2020). Commonly used ICT platforms for ERTL include Learning Management Systems (LMS), online video communication and social media platforms (Jena, 2020; Rahiem, 2020). It is on these platforms that participants engage synchronously or asynchronously via lectures, discussions and assessments (Rahiem, 2020) in learning. This study identified and described the undergraduate students' encounters during ERTL, perceptions and preferences for ERTL, in a selected HEI. Whilst several authors such as Naidoo (2020), Sokhulu (2020), Obuaku-Igwe (2020) and Songca et al. (2021) carried similar studies in South Africa, a common characteristic of their studies is that they focused on experiences on limited aspects of ERTL. Naidoo and Sokhulu's studies focused on experiences of digital platforms; Obuaku-Igwe considered social isolation experiences whilst Songca et al, considered access to study materials and participation efficacy. This study considers experiences from the whole remote learning process except for assessments, which most lecturers have not started administering by the time of collecting data for the study. It looked at the experiences from interactions with lecturers and learning content on platforms used and the interactions with learning content in their home environments.

\section{Background to the selected Higher Education Institution}

Like many other HEls in South Africa, the selected institution shifted from its blended but primarily face-to-face teaching and learning mode to ERTL. Blackboard, customised as WiseUp for the selected HEI, was the official learning management system (LMS) adopted.

Because most students did not have the required ICT tools and data for connection and some lecturers needed some training to enable ERTL, the institution did not move to ERTL immediately after the lockdown. The institution addressed some of these challenges by training its staff members and providing ICT tools and data for both lecturers and students who were in need. Training of staff members, especially lecturers, was necessary as it has a direct impact on teaching methods which in turn, impact on student learning (Idika, 2020). The delay in moving to remote learning meant that the academic calendar had to be adjusted several times, a common feature for other HEls (Czerniewicz et al., 2020). This meant that lecturers and students had to complete syllabi in a condensed calendar, which could have been a source of stressful experiences. 
Matarirano, O. et al. Students' Responses to Multi-Modal Emergency Remote Learning During COVID-19 in a South African Higher Institution

The HEI moved to ERTL after the provision of the enablers but yet encountered a challenge with its LMS that could not cope with increased traffic flow. This led to lecturers being limited to few functions of the LMS, further affecting the academic plans. Because of the temporary malfunctioning of the LMS, the institution's management informed lecturers to use various approaches and platforms for teaching. Whilst the decision enabled learning to continue, it exposed students to multiple approaches and platforms, which could have been frustrating for students as claimed by Pincock (2020). Transitioning to technology during remote learning could overwhelm the students at home, learning how to use the new tools correctly and adapting to a new learning setting (Kalimullina et al., 2021; O'Scanaill, 2020).

\section{Research questions}

It is against this backdrop that the study explored the experiences of students to ERTL by answering the following questions:

- What were the students' encounters with ERTL at the selected HEI during the selected period?

- What were the perceptions of the selected HEl's students to ERTL during the selected period?

- What is the preferred learning approach of the students from the selected HEI?

\section{Literature review}

Since COVID-19 induced lockdowns, which led to the closure of HEls and the adoption of ERTL, many studies have been carried out to explore the experiences of students around the world (Amin \& Sundari, 2020; Benito et al., 2021; Ewing \& Cooper, 2021; Ghazi-Saidi et al., 2020). ERTL is considered to be a double-edged sword in that it enabled learning to take place during the COVID-19 pandemic but also constrained effective learning (Ewing \& Cooper, 2021). It is considered to be flexible and convenient (Serhan, 2020) and some authors claim that it caused feelings of disengagement, demotivation and isolation among students (Parker et al., 2021). Although ERTL enabled learning to take place, it exposed and exacerbated the digital divide between students (Krönke, 2020; Shin \& Hickey, 2020; Williams et al., 2021). Whilst on campuses, students had access to ICT equipment, stable internet connection and did not require data for internet connection as $\mathrm{Wi}-\mathrm{Fi}$ was provided by $\mathrm{HEI}$. These enablers are unavailable at most students' home environments, widening the digital gap between students from poor families and rich families.

\section{Theoretical perspective: Sociocultural Theory}

Vygotsky's sociocultural theory of learning and development (1978) was used to understand the experiences of students during remote learning and the related effects on learning. Vygotsky (1978) argued that learning happens in social contexts and underscored the importance of interactions and culture. He argued that learning was a product of sociocultural interactions of individuals and their participation in knowledge practices of a community and supported by others in the community who are more knowledgeable than them. Students learn in social contexts through interactions with their peers, teachers and other experts. Learning takes place when students interact and collaborate with more knowledgeable others, which could be teachers and or peers (Vygotsky, 1978). Teachers facilitate learning by creating a 
Matarirano, O. et al. Students' Responses to Multi-Modal Emergency Remote Learning During COVID-19 in a South African Higher Institution

learning environment that maximises the student's ability to interact with other students through discussions, collaborations and feedback (Neff, 2021). The interactions among students, lecturers and the contextual features of classrooms through activities, impact the motivation of students, which influences their learning. Activities in classrooms refer to what lecturers and students, and students and students say to and do with one another (Perry et al., 2006).

The use of remote learning meant that some student interactions in the selected HEls, which were primarily face-to-face, were disrupted. Whilst it was still possible to continue with interactions using online platforms, factors such as lack of compatible devices, inconsistent supply of electricity, unstable internet network, high cost of data and unconducive home environments negatively impact the quality and extent of interactions. The established experiences are discussed considering the online student interactions, which are considered by Vygotsky to be critical for effective learning.

\section{Factors that influence interactions in remote learning}

\section{ICT-related factors and electricity}

To effectively engage in ERL, students require the basics of e-learning that include electricity, digital devices, internet connection and data (Czerniewicz et al., 2020), which are unavailable to some students (Mohmmed et al. 2020; Ferri et al., 2020). Online interactions are possible with digital devices such as smartphones, tablets/iPad and computers. In their exploration of students' readiness for digital learning, Arthur-Nyarko at al. (2020) claim that access to digital technologies creates the foundation for implementing technology-enabled learning. The devices, which are mostly battery-powered, need electricity for recharging. A stable internet connection is another requirement for online interactions. Access to electricity and stable internet have a greater impact on students who reside in remote rural areas where there is no or erratic supply of electricity and limited or no ICT infrastructure (Ferri et al., 2020; Shim \& Lee, 2020). Most students from the selected $\mathrm{HEl}$ live in rural areas and their interactions during $\mathrm{ERL}$ are curtailed by lack of electricity and unstable internet connections. Even with the aforementioned requirements, online interactions are impossible without data that enables internet connection. Many students confessed that remote learning required a lot of data, which does not come cheaply (Shim \& Lee, 2020). The cost of data in South Africa is very high (Naidoo, 2020; Rossouw, 2018), thus inhibiting the poor students' access to learning and reducing their chances of success.

\section{Technology use proficiency}

Whilst having digital devices, electricity, stable network and data improved the chances of interactions, the actual interactions depend on the ability of students to use the technology for learning. Although most students are digital natives (Prensky, 2001) and are experienced users of technology (Basol et al., 2018), their proficiency is primarily in social media, which may not assist much in understanding technology for learning (Nami \& Vaezi, 2018). The proficiency is even worse for students from poor economic backgrounds who are not exposed to the digital platforms for learning until they join universities (Czerniewicz et al., 2020). Exposure to technology improves students' e-learning self-efficacy (Khalifeh et al., 2020) and technology 
Matarirano, O. et al. Students' Responses to Multi-Modal Emergency Remote Learning During COVID-19 in a South African Higher Institution

proficiency (McCoy, 2010), which are relevant to meaningful students' engagements with learning.

\section{Home environments}

The study environment is another factor that affected ERL. During the national lockdowns, most students had to go back to their homes. Whilst the home environments provided a comfortable learning environment for some students (Parker et al., 2021), they impeded many with financially-poor backgrounds and family responsibilities (Mohmmed et al., 2020; ObuakuIgwe, 2020; Shin \& Hickey, 2020). Many studies considered home environments unconducive for learning (JISC, 2021; Kaisara \& Bwalya, 2020) as several students did not have a dedicated space to work, undisturbed (Wilcox \& Vignal, 2020) which negatively affects student learning.

\section{Student experiences of remote learning}

Positive experiences

Experiences of students during ERL have been mixed, with reports of improved learning and some negative experiences (Ewing \& Cooper, 2021; Wise \& Bergner, 2020). Remote learning promoted the anytime anywhere learning (Mazana, 2018) and reached people who would have been inaccessible (Yuhasriati et al., 2020). Students enjoyed the comfortable home environments, efficient time utilisation, smooth interaction (Benito et al., 2021; Shim \& Lee, 2020), flexibility, convenience (Wise \& Bergner, 2020) and the freedom to structure their learning (Jena, 2020; Parker et al., 2021). They had no obligation to attend lectures in cramped lecture venues and could learn in more relaxed environments (Parker et al., 2021), improving their concentration levels (Pincock, 2020). Remote learning was also desirable to students who commute to and from university campuses, as it saved them time (Yuan, 2021) and money (Krige, 2020).

Besides its flexibility and convenience, ERL granted students more opportunities for interaction with their lecturers and peers (Huang et al., 2020). Live streaming established a sense of community (Yuan, 2021) and promoted interaction by providing a less intimidating learning environment (Pincock, 2020), and encouraging introverts to participate (Ghazi-Saidi et al., 2020) without being concerned about the attention of peers and lecturers (Serhan, 2020). The ability of students to ask questions in remote learning contributed to their positive experiences (Parker et al., 2021). Students who preferred remote learning commented on the easiness of communicating with lecturers and peers and less distraction from friends and classmates (Sokhulu, 2020; Vale et al., 2020).

The use of videos and recordings was highly appreciated by students (Naidoo, 2020) who were keen to utilise recordings for learning (Yuan, 2021) and as a result, reported enhanced learning experiences (Benito et al., 2021; Vale et al., 2020). Recordings have been reported to improve students' interaction with the course content as they paid more attention to synchronous engagements instead of focusing on note-taking (Nkomo \& Daniel, 2021). Lecture recordings are a critical resource for review to students who got lost in a class (Czerniewicz et al., 2020) or did not understand a concept because of its complexity or difficulties in understanding the lecturer (Nkomo \& Daniel, 2021). Yuan (2021) argues that recorded videos assist students to 
Matarirano, O. et al. Students' Responses to Multi-Modal Emergency Remote Learning During COVID-19 in a South African Higher Institution

connect and understand concepts better, which they can achieve by replaying the video whenever they desire.

\section{Negative experiences}

Although students had positive experiences with remote learning, they also had unpleasant ones. For some students, words such as anxious, frustrated, distressed and overwhelmed were used to describe their experiences (Almoayad et al., 2020; Subedi \& Subedi, 2020; Wise \& Bergner, 2020). Contrary to the claim by Ghazi-Saidi et al., (2020) and Yuan (2021) that engagements improved with ERL, many studies revealed a reduction in engagement levels (JISC, 2021; Parker et al., 2021; Shin \& Hickey, 2020; Wise \& Bergner, 2020). Turn-taking in synchronous classes inhibited effective interactions as more than a single person could talk discouraging others from participating (Wise \& Bergner, 2020).

There is a general distraction associated with online learning, which negatively affected student learning experiences (Vale et al., 2020). Students could easily be distracted by other activities such as Web browsing (Mohmmed et al., 2020) and chatting on social media platforms (Parker et al., 2021) during synchronous sessions and home experiences where most students did not have private study spaces (Parker et al., 2021; Serhan, 2020). These distractions led to many students losing motivation to learn (Ghazi-Saidi et al., 2020; Shin \& Hickey, 2020).

Social isolation was also a major issue and most students felt isolated from their peers and lecturers (Benito et al., 2021; Kaisara \& Bwalya, 2020; Shim \& Lee, 2020). Students decried the lack of interpersonal experiences and connections with other students (Wise \& Bergner, 2020). ERL was considered to be less personalised (Ewing \& Cooper, 2021) and students did not feel a sense of community (Shin \& Hickey, 2020).

Yet, the findings of varying and contrasting experiences are expected as students do not have homogeneous learning patterns (Arora et al., 2011) and previous experiences (Ghazi-Saidi et al., 2020), thus their experiences with ERL would be different. In addition, the students were exposed to different structures and cultural environments that influenced their experiences.

\section{Methods}

\section{Design}

A cross-sectional descriptive study was carried out to describe the experiences of students with remote learning from the time when face-to-face interactions were replaced by remote teaching until the end of August of 2020. The experiences included students' encounters, perceptions and preferences. The study followed a survey research design, utilising an online questionnaire with closed-ended questions. Surveys are considered most appropriate for measuring unobservable data such as factual information, preferences, attitudes, beliefs and behaviours (Nayak \& Singh, 2015).

\section{Sampling procedures}

A non-probability convenience sampling was used to identify respondents. The survey instrument was administered to returning students enrolled in the Department of Accounting and Finance (DoAF) in one campus of the selected institution. The study targeted returning students because they were more familiar with the institution's structures and cultures and 
Matarirano, O. et al. Students' Responses to Multi-Modal Emergency Remote Learning During COVID-19 in a South African Higher Institution

experienced face-to-face learning before COVID-19-induced lockdowns. As a result, they were able to provide meaningful assessments on the shift to ERT. The DoAF had 649 registered returning students in the first semester of the 2020 academic year. After a week of sharing the questionnaire, 243 students responded. The general characteristics of the respondents are summarised in Table 1.

Table 1. General characteristics of respondents

\begin{tabular}{|lccc|lc|}
\hline Age & Female & Male & Total & Study Level & Frequency \\
\hline Below 20 years & 8 & 2 & 10 & Second & 93 \\
20 - 25 years & 106 & 48 & 154 & Third & 115 \\
25 - 30 years & 37 & 18 & 55 & Fourth & 35 \\
30 - 35 years & 14 & 6 & 20 & & \\
Over 35 years & 3 & 1 & 4 & & \\
\hline Grand Total & 168 & 75 & 243 & & 243 \\
\hline
\end{tabular}

As portrayed in Table 1, the total number of students who responded to the questionnaire was 243 of which $69 \%$ were females whilst $31 \%$ were males. The level of study which had the highest representation was the third year, which made $47 \%$ of the respondents. The age class of $20-25$ years had the most respondents comprising $63 \%$ of the sample.

\section{Research Instrument}

A self-administered questionnaire developed by the researchers based on the research questions of the study was used to gather data. The questionnaire had five sections. The first section solicited socio-demographic information such as gender, age and level of study. The second section identified the ICT tools, platforms and approaches used during ERL. Section three had nine items that were used to establish the encounters of respondents during the period under study. The fourth section had seventeen items that required respondents to indicate their feelings about ERL on a Likert Scale. Nine of the 17 items solicit feelings about the learning platforms and approaches used as well as the interactions with lecturers. The remaining items related to preferences and reasons behind the identified preferences. The last section required respondents to indicate their preferred learning platforms but the findings are not reported in this paper.

\section{Reliability and validity}

The internal consistency of the 17 items that were used to explore the perceptions of students was established by calculating Cronbach's Alpha whilst validity was established by extracting factor loadings from the principal component analysis. Cronbach's Alpha and factor loadings were calculated using SPSS. A Cronbach's Alpha value of 0.827 was obtained, which showed high internal consistency reliability. As a rule of thumb, values above 0.6 for Cronbach's Alpha indicate a reliable research instrument (Sarosa, 2019). For a research instrument to be reliable, the rotated factor loadings of any item should not be less than 0.4 (Rahn, 2021). All items had factor loadings above 0.4. The reliability and validity scores obtained show the adequacy of the research instrument in measuring the perceptions of students during the selected period of ERL. 
Matarirano, O. et al. Students' Responses to Multi-Modal Emergency Remote Learning During COVID-19 in a South African Higher Institution

\section{Data collection procedures}

The study implored responses from literate participants, thus making a self-administered questionnaire an appropriate measurement tool. Data were collected from the 30th August 2020 to the 4th of September 2020, which was towards the end of the COVID-19 adjusted first semester. The end of the semester was selected because it allowed students enough time to experience ERL. A hyperlink to the questionnaire was shared via class WhatsApp groups. Key ethical issues were addressed throughout the research, especially during the data gathering and analysis stages. All respondents were informed about the purpose of the study and how the information generated was to be used. Confidentiality was guaranteed and highlighted in the introduction of the google form used for data collection. Respondents were informed of their right to privacy and refusal to participate at any point in the survey.

\section{Data analysis}

The data analysis process began by downloading responses from google forms to MS Excel and then cleaning it for missing responses. The data presented only one missing response on the ICT devices used by respondents, which was not reported in this paper. Data from MS Excel was exported to SPSS for reliability and validity testing. In attempting to understand the meaning of the data relating to student encounters during the study period, bar charts in MS Excel, were used to present the frequencies of each pre-identified encounter. The visualisation of the results made the interpretation and understanding of the data easier. The perfections and preferences of students were analysed using item statistics of the Likert scale generated from the descriptive statistics of SPSS. The five-point Likert scale was reduced to three points including strongly agree and agree; neutral; disagree and strongly disagree. The item statistics included percentages of options selected for each item and the means for each item. The percentages of the options for each item represent the position of respondents regarding that item; the higher percentages represent the majority position of respondents. The mean represents the average response to each item and ranges between 1 and 5 with 2.5 as the middle point. A mean above 2.5 implies responses skewed towards agreeing with a statement whilst below 2.5 shows disagreeing with a statement.

\section{Findings}

The purpose of this study was to identify and describe the encounters of students and their perceptions and preferences about remote learning. To have a better understanding of the experiences of respondents, it is necessary to present the general teaching approaches used by lecturers in their engagements with students. These approaches are summarised in Figure 1. The results of the students' encounters, perceptions about remote learning and preferences in remote learning are presented thereafter.

\section{Approaches used for ERT}

Respondents were requested to select the approaches used by lecturers in ERT. Their responses are summarised in Figure 1. 
Matarirano, O. et al. Students' Responses to Multi-Modal Emergency Remote Learning During COVID-19 in a South African Higher Institution

Figure 1. Approaches used for ERT

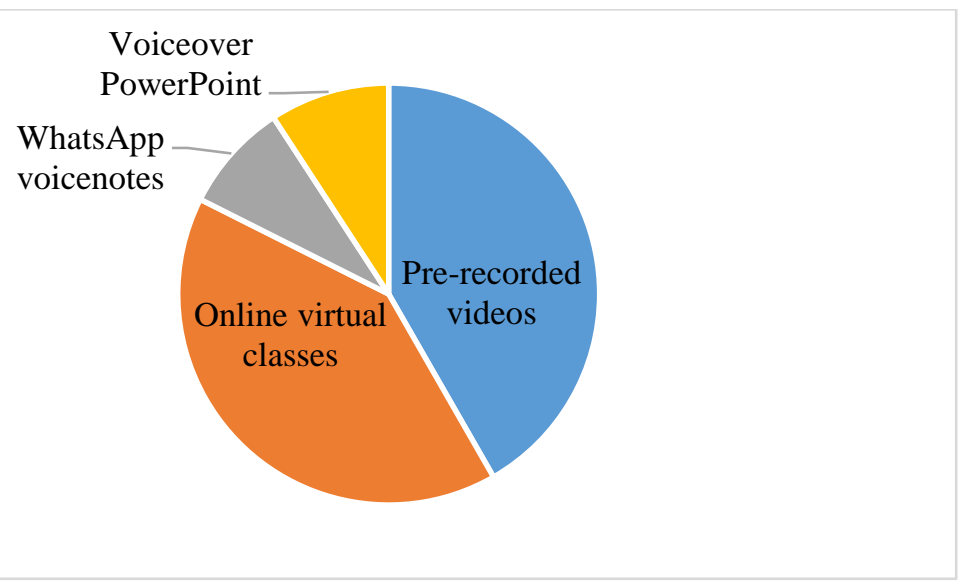

The approaches used for ERT, as presented in Figure 1, included asynchronous pre-recorded class videos and class recordings, WhatsApp voice notes and voiceover PowerPoint whilst virtual classes were used for synchronous engagements. Pre-recorded videos and virtual classes, which were also recorded, were the commonly used approaches for ERT. The primary reasons for having pre-recorded videos or recording classes were to enable access to students who would have missed classes due to various reasons such as unstable network, insufficient data for connectivity and family responsibilities among others.

\section{Students' encounters during ERL}

From a list of encounters, respondents were asked to select encounters during remote learning. Their responses are summarised in Figure 2.

Figure 2. Student encounters during ERL

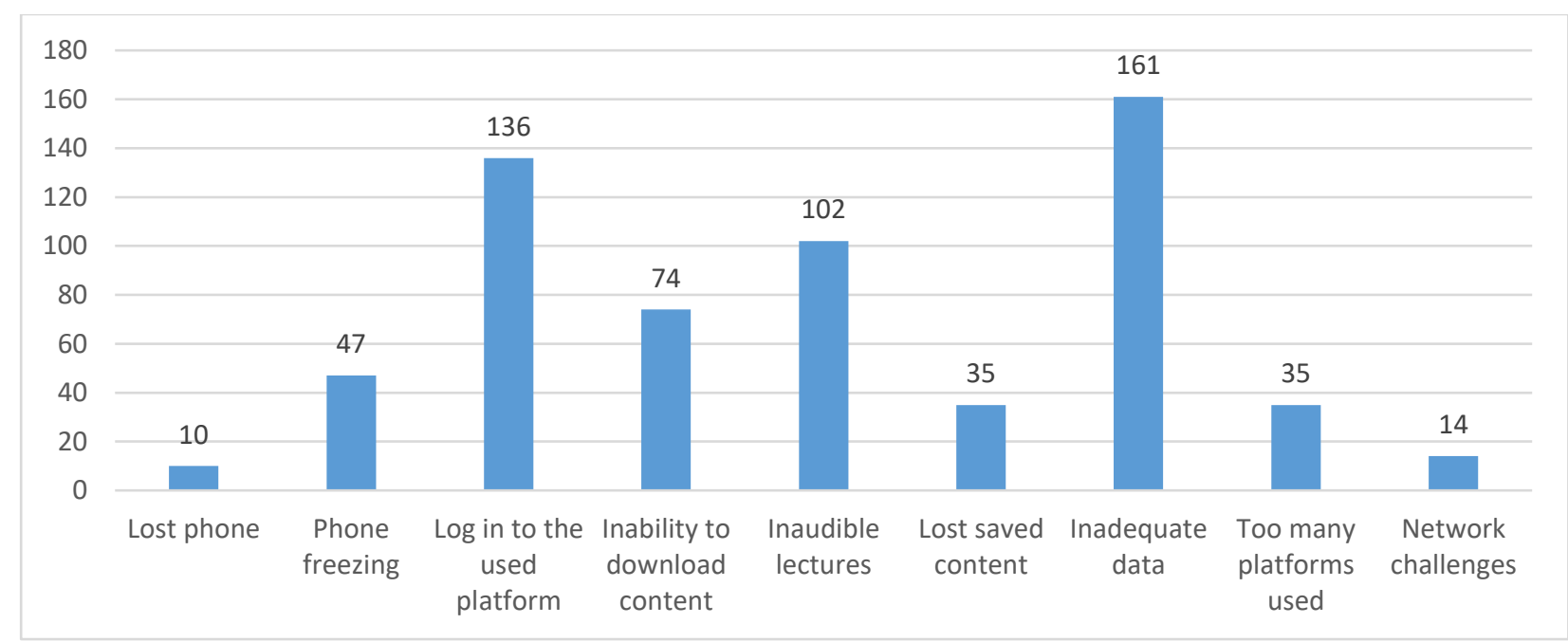

As Figure 2 portrays, the major encounters students had with ERL included struggles to log in to learning platforms, inability to download learning content, inaudible synchronous lectures and insufficient data. The most frequently selected encounter was running out of data for engagement with learning. Students were provided with data that was expected to last them for a month but this was not enough for the learning required. Students were expected to 
Matarirano, O. et al. Students' Responses to Multi-Modal Emergency Remote Learning During COVID-19 in a South African Higher Institution

attend synchronous virtual classes, download course content, search information for assignments and engage in peer discussions amongst other activities. It is also possible that students used the provided data for socialisation, which may be necessary for learning motivation. The other encounters selected included trouble in logging into learning platforms, difficulties in downloading content and inaudible lectures that reflected unstable networks.

\section{Perceptions about ERL}

The perceptions of students about the learning platforms used, teaching approaches as well as their engagements with lecturers are summarised in Table 2.

Table 2. Perceptions about ERL

\begin{tabular}{|c|c|c|c|c|}
\hline Item & \begin{tabular}{|l|} 
Strongly \\
Disagree/Disagree
\end{tabular} & Neutral & $\begin{array}{l}\text { Agree/Strongly } \\
\text { Agree } \\
\end{array}$ & Mean \\
\hline $\begin{array}{l}\text { I enjoy the flexibility of learning using online } \\
\text { platforms }\end{array}$ & $59 \%$ & $22 \%$ & $19 \%$ & 2.3580 \\
\hline $\begin{array}{l}\text { I like recorded classes/videos because I can } \\
\text { watch them anytime }\end{array}$ & $14 \%$ & $20 \%$ & $66 \%$ & 3.7037 \\
\hline $\begin{array}{l}\text { I like recorded classes/videos because I can } \\
\text { watch them at any place }\end{array}$ & $16 \%$ & $22 \%$ & $62 \%$ & 3.6502 \\
\hline $\begin{array}{l}\text { I like recorded classes/videos because I can } \\
\text { pause and or rewind }\end{array}$ & $11 \%$ & $19 \%$ & $70 \%$ & 3.7654 \\
\hline $\begin{array}{l}\text { Lecturers take long to respond to queries raised } \\
\text { on platforms }\end{array}$ & $62 \%$ & $27 \%$ & $11 \%$ & 2.2469 \\
\hline $\begin{array}{l}\text { Lecturers do not respond to queries raised on } \\
\text { an online platform }\end{array}$ & $80 \%$ & $15 \%$ & $5 \%$ & 1.9753 \\
\hline $\begin{array}{l}\text { Lecturers do not constantly visit the learning } \\
\text { platforms used }\end{array}$ & $76 \%$ & $15 \%$ & $9 \%$ & 2.0864 \\
\hline $\begin{array}{l}\text { Lecturers do not actively engage me on the } \\
\text { platforms used }\end{array}$ & $61 \%$ & $26 \%$ & $13 \%$ & 2.3786 \\
\hline $\begin{array}{l}\text { I get frustrated by the use of different platforms } \\
\text { by lecturers }\end{array}$ & $26 \%$ & $22 \%$ & $52 \%$ & 3.2634 \\
\hline
\end{tabular}

In attempting to understand the perceptions of students in interacting with learning content, synchronously and asynchronously, they were asked to indicate their feelings about the learning platforms used, the lecture and class recordings as well as their interactions with lecturers. Table 2 presents the responses to the statements provided. Most respondents did not enjoy the flexibility of online platforms, contrary to what is claimed in literature. The mean responses to the statement on whether they enjoyed the flexibility of online platforms were below the mid-point of 2.5 , implying negative perceptions towards used platforms. The responses to this item could have been influenced by the challenges respondents encountered during remote learning. As portrayed in Figure 2, respondents had insufficient data as well as having difficulties in logging into learning platforms, downloading learning content and hearing lecturers during synchronous interactions.

Regardless, the respondents appreciated the flexibility of pre-recorded lectures and recorded classes, which were considered being convenient. As shown in Table 2, students appreciated recorded content as they could access it at any time, any place and could pause, rewind and fast forward, allowing them to study at their own pace. Class recordings and videos provided 
Matarirano, O. et al. Students' Responses to Multi-Modal Emergency Remote Learning During COVID-19 in a South African Higher Institution

another opportunity for students who would have missed the synchronous classes because of a myriad of reasons.

The presence of the lecturer on the learning platforms is critical if students are to have meaningful engagements with learning content. Engagements between students and lecturers are through learning platforms, emails and social media networks. Respondents were requested to indicate their feelings about how the lecturers engaged with them to better understand the learning content. Most respondents were content with the efforts and support of the lecturers as shown in Table 2. Responses showed that lecturers showed compassion and were supportive of students. They claimed that lecturers responded to their queries on time, were visible on the learning platforms and actively engaged them on the platforms. The only source of frustration from interaction with lecturers was the use of different platforms for different subjects. This could be because students were serviced by other departments for specialised courses such as commercial law and statistics that are housed in other departments separate from DoAF.

\section{Preferences of learning approach}

Table 3 presents the responses to statements about respondents' preference between faceto-face classes and online learning as well as reasons provided for those who preferred learning face-to-face on campus.

Table 3. Preferences for learning approach

\begin{tabular}{|l|l|l|l|l|}
\hline Item & $\begin{array}{l}\text { Strongly } \\
\text { Disagree/Disagree }\end{array}$ & Neutral & $\begin{array}{l}\text { Agree/Strongly } \\
\text { Agree }\end{array}$ & Mean \\
\hline $\begin{array}{l}\text { I prefer learning online to a classroom } \\
\text { I prefer attending classes on campus because: }\end{array}$ & $77 \%$ & $13 \%$ & $10 \%$ & 1.9095 \\
I do not have adequate study space & $20 \%$ & $19 \%$ & $61 \%$ & 3.3580 \\
I do not have enough study time & $20 \%$ & $22 \%$ & $58 \%$ & 3.4074 \\
I have a poor network connection & $21 \%$ & $22 \%$ & $57 \%$ & 3.3086 \\
I do not have adequate data for connection & $20 \%$ & $23 \%$ & $57 \%$ & 3.3045 \\
I do not have proper ICT equipment & $34 \%$ & $24 \%$ & $42 \%$ & 3.0082 \\
It is difficult to concentrate when studying from \\
home
\end{tabular}

As Table 3 shows, most respondents preferred face-to-face, on-campus learning compared to online learning. A paltry $10 \%$ preferred online learning compared to $77 \%$ that were against it. A mean score of less than 2.5 shows that online learning was unpopular with the respondents. The respondents were requested to select reasons for preferring face-to-face interactions. The reasons selected for the preference of face-to-face learning approach ranged from unconducive home environments, ICT-related, to social relations factors. Most respondents indicated not having enough time and space to study and difficulty in concentrating at home environments. In addition, their preference for face-to-face interactions was partly informed by the lack of personal relationships in remote learning. Thus, they could not learn from each other through collaborations and discussions. Students get motivation by engaging with their peers and a lack of interaction may demotivate them to engage with content, chiefly, if the 
Matarirano, O. et al. Students' Responses to Multi-Modal Emergency Remote Learning During COVID-19 in a South African Higher Institution

content is challenging. With all reasons provided, the means, as shown in Table 3 , were above 2.5 proving their preference for face-to-face interactions on campus. Of all reasons, the lack of digital devices had the least effect on their perceptions. Still, it was expected that students would not consider a lack of digital devices as an inhibitor to remote learning as most students received laptops.

\section{Discussion}

The study intended to identify the encounters of students during remote learning, their perceptions of remote learning and their preferred approaches to learning. The results show that the students who participated in the survey had insufficient data for learning, had unstable network connections which resulted in struggling to log in to learning platforms, downloading learning content and hearing lectures in synchronous classes. In terms of perceptions, most respondents did not enjoy the flexibility of online learning platforms. However, they appreciated the benefits associated with recorded learning content and classes. The respondents also considered their interactions with lecturers to have been fruitful and they perceived lecturers to be compassionate and affective in the interactions. Most respondents preferred to go back to face-to-face classes on campus to learning online. These findings are the subject of the following discussion.

The findings provide evidence that the level and quality of interactions between students and lecturers and students and students, which are critical to learning, as argued by Vygotsky (1978), were greatly affected. Besides student-lecturer and student-student interactions, the studentcontent (Moore, 1989) interaction was also affected. Moore (1989), in his discussion on students' interactions in distance learning, argued that students need to interact with content, lecturers and other students for effective learning to take place. Any factors that do not promote these interactions would negatively affect student learning and reduce their chances of success.

\section{Encounters of students during ERL}

The major encounter of respondents during remote learning was insufficient data for engagements with learning. This finding was expected as most respondents are from disadvantaged families, do not have internet access at home and cannot afford to buy data, which is considered to be expensive in South Africa (Naidoo, 2020; Rossouw, 2018). Inadequacy of data makes engagement with learning content, lecturers and peers a challenging exercise. However, this encounter is not isolated to the respondents in this study as other studies around the world found insufficient data to be an issue for meaningful remote learning (Kaisara \& Bwalya, 2020).

The struggles of respondents to log in to learning platforms, inability to download learning content and inaudible lectures during synchronous classes highlight the unstable network that most students encountered. An unstable network connection has been cited in several studies as one of the major obstacles to remote learning in both the developing (Kaisara \& Bwalya, 2020; Songca et al., 2021) and developed world (Wilcox \& Vignal, 2020; Williams et al., 2021). Students with poor internet connections cannot fully engage with content, interact with peers and lecturers online, which makes ERL a struggle for them (Shin \& Hickey, 2020; Vale et al., 2020). Inability to engage with content, especially in synchronous interactions, negatively 
Matarirano, O. et al. Students' Responses to Multi-Modal Emergency Remote Learning During COVID-19 in a South African Higher Institution

affects students' chances of success (Benito et al., 2021) as attendance affects performance (Vale et al., 2020). Similar to insufficient data, an unstable internet connection reduces the levels of interactions between students and learning content, their lecturers and peers, thus reducing their chances of success. Learning is considered a social and cognitive engagement (Shin \& Hickey, 2020), so a lack of social interaction impedes effective learning (Almoayad et al., 2020).

\section{Students' perceptions about ERL}

Despite the negative experiences of remote learning, many respondents appreciated the use of lectures and class recordings. Use of recordings put students at ease as they could access the learning content they could have missed and gave them another opportunity to interact with learning content. In addition, recordings also provided flexibility and convenience for learning. With recordings, students could get clarification on concepts missed out in classes, access the content when they had time and 'quietness'. They could download content when they had data and a stable network and could study offline. This was very important as the data package students received, as a result of the negotiation between the selected institution and network providers, had more night proportion data than daytime. Having recordings available anytime meant that students could utilise this data by downloading the videos at night. Students could also rewind, pause and fast-forward recordings to improve their understanding. This finding is echoed in many prior studies that claim recordings to be useful to students (Benito et al., 2021; Naidoo, 2020; Vale et al., 2020; Yuan, 2021) and are preferred to synchronous instruction (Songca et al., 2021). These studies argue that recordings benefit students by enhancing engagement, supplementing classes (Nkomo \& Daniel, 2021), providing an alternative to missed classes (Mohmmed et al., 2020) and allowing students to review unclear concepts (Czerniewicz et al., 2020; Yuan, 2021).

The respondents also acknowledged the efforts of lecturers in making their experiences in remote learning bearable. They claimed that lecturers actively interacted with them on various platforms, provided timely responses to queries/consultations and were flexible, which improved their engagements with learning content. Such presence could have improved the learning of students as lecturers' active involvement is critical to providing support and encouragement (Aristovnik et al., 2020). Many studies carried out to assess the experiences of students during remote learning also found lecturers to be compassionate and made themselves available for interactions with students (Songca et al., 2021; Yuan, 2021). The only concern with respondents regarding their interactions with lecturers was the use of multiple platforms for engagements. This concern was likely to result from no specific guidance being provided for student instruction and lecturers were likely to use methods they were comfortable with. In addition, students were, in some subjects, instructed by lecturers from departments other than the DoAF. Whilst it could be easier for lecturers from the same department to agree on using similar platforms, the same could not be said about different departments which adopted and recommended different platforms.

\section{Students' learning preferences}

Asked if they would prefer learning online or face-to-face on campus, it is unsurprising that most respondents preferred being on campus compared to learning online. Face-to-face 
Matarirano, O. et al. Students' Responses to Multi-Modal Emergency Remote Learning During COVID-19 in a South African Higher Institution

interactions gave them meaningful interactions and increased their chances of success. The benefits of remote learning such as flexibility and convenience (Benito et al., 2021; Serhan, 2020) were overshadowed by the negative experiences associated with remote learning. This finding is shared by Benito et al., (2021) who found face-to-face classes to be more effective to learning than remote learning. University campus environments provide resources and study spaces that are missing in most home environments. At home, most students, who share spaces with their families, have many family responsibilities and home chores, which limit the time they have for interacting with learning content. This challenge is worse for students who are parents or females as they have to take care of their families, in addition to studying full time (Czerniewicz et al., 2020; Shin \& Hickey, 2020). The home environments have several disturbances that make concentration almost impossible as most respondents in the study alluded. This argument is supported by Vale et al., (2020) who found that it is easier for students to concentrate in face-to-face classes than in online environments. Adding to study spaces and study time, students from most rural areas do not have electricity, which further limits the extent of all relevant interactions. Most of the identified challenges resonate with the challenges faced by students in remote learning, which include lack of quiet study spaces, no access to campus resources, additional familial responsibilities and unreliable internet connection (Wilcox \& Vignal, 2020). The campus environments neutralise the negative experiences associated with home environments by providing study spaces, ICT-related resources as well as places for social interaction. According to UNESCO (2020), university campuses are hubs of social activity and human interaction, which are essential to learning and development.

Remote learning denied students an opportunity for physical and social engagements with peers, negatively affecting their social life. Rodriguez-Segura et al., (2020) argue that the social life of students plays a huge role in their learning, which is in line with the sociocultural learning theory which argues that learning occurs in social contexts through interactions (Vygotsky, 1978). According to Hurst et al., (2013), social interaction improves student learning by enhancing their critical thinking and problem-solving skills. Okita (2012) claims that interacting with other people assists students in organising their thoughts, reflecting on their understanding and finding gaps in their reasoning. In African societies that practice a culture of 'ubuntu', where there is a dependency on each other, isolation may cause a sense of being lost, which may lead to a loss of desire and motivation to learn. Online social interactions are hindered by insufficient data and unstable network connections.

The findings of this study point to the mixed feelings students experience during remote learning. This is because, as much as remote learning brought inequalities between students to the fore, it also provided several opportunities that were not fully explored pre-Covid-19. As Ewing and Cooper (2021) claimed, remote learning evoked both positive and negative experiences from students as it aided and inhibited student interactions with learning content, lecturers and peers. Insufficient data, unstable networks, unconducive home environments and use of multiple platforms reduced the level of interactions whilst the use of recorded materials and availability of lecturers to students when there was a need, improved the interactions.

This study adds to the body of knowledge for online learning and how decisions for online should have a student's voice if they are to be effective. In making decisions about online 
Matarirano, O. et al. Students' Responses to Multi-Modal Emergency Remote Learning During COVID-19 in a South African Higher Institution

learning, the findings of the study show that the primary focus must be on student learning and not necessarily how versatile lecturers may be when using online platforms. The choice of learning approaches and platforms should not be left to the lecturers but involve students. Such decisions would lead to students focusing on learning rather than other issues such as learning platforms, which disrupt them learning.

\section{Limitations and areas for further research}

Although the findings of this study conform to findings from other similar studies, the study was exclusive, making the findings ungeneralisable. First, the sample was from one department, which is not representative of all students of the selected HEI. The short time provided to respond (one week) may have excluded students who did not have data, network or ICT tools at the time data was collected. A longer data collection period might have improved the number of responses and be more inclusive. The study excluded students who had no WhatsApp at the time of administering the survey instrument. Interactions with assessments were excluded from the study, which could have broadened the insights into the remote learning experiences. In addition, the study did not get qualitative explanations for the experiences and perceptions during ERTL. Future studies need to consider qualitative explanations of the experiences and also consider the effects of different societal structures such as gender on student experiences in remote learning.

\section{Conclusion}

The study findings showed that students encountered a number of challenges, key among them being insufficient data, and unstable network connection. They also decried unconducive home environments which made them prefer being on campus. Their preference for face-to-face oncampus learning may therefore, not be a sign of dislike for online learning but a reflection of the challenges they encountered during remote learning. Most of the challenges experienced are not new to most students but they were exposed by ERTL. The university campuses concealed these deep social inequalities that exist within South African societies. Regardless of these negative experiences, they appreciated the use of recorded material and the compassion of lecturers.

Although the findings of the study cannot be generalised, they provide a resource for proper planning of teaching and learning, not only during pandemics but also for the future of elearning. The findings show that online learning will not be feasible with all the challenges students encountered when learning from home. Effective engagements, which are inhibited by the circumstances of home environments, are only possible with students being on campus. The findings also point to the need for lecturers to consider the challenges students encounter in their plans for teaching and learning. The lessons learnt from studies such as this help in planning for the future of teaching and learning. 
Matarirano, O. et al. Students' Responses to Multi-Modal Emergency Remote Learning During COVID-19 in a South African Higher Institution

\section{References}

Almoayad, F., Almuwais, A., Alqabbani, S. F., \& Benajiba, N. (2020). Health professional students' perceptions and experiences of remote learning during the COVID-19 pandemic. International Journal of Learning, Teaching and Educational Research, 19(8), 313-329. https://doi.org/10.26803/ijlter.19.8.17

Amin, F. M., \& Sundari, H. (2020). EFL students' preferences on digital platforms during emergency remote teaching: Video conference, LMS, or Messenger Application? Studies in English Language and Education, 7(2), 362-378.

https://doi.org/10.24815/siele.v7i2.16929

Aristovnik, A., Keržič, D., Ravšelj, D., Tomaževič, N., \& Umek, L. (2020). Impacts of the COVID19 pandemic on life of higher education students: A global perspective. Sustainability, 12(20), 1-34. https://doi.org/10.3390/su12208438

Arora, A., Leseane, R., \& Raisinghani, M. S. (2011). Learning and Teaching Styles for Teaching Effectiveness: An Empirical Analysis. International Journal of Web-Based Learning and Teaching Technologies, 6(1), 1-13.

Arthur-Nyarko, E., Agyei, D. D., \& Armah, J. K. (2020). Digitizing distance learning materials: Measuring students' readiness and intended challenges. Education and Information Technologies, 25(4), 2987-3002. https://doi.org/10.1007/s10639-019-10060-y

Basol, G., Cigdem, H., \& Unver, T. K. (2018). Variables explaining the online learning readiness level of students: Turkish vocational college example. European Journal of Education Studies, 4(10), 14-32. https://doi.org/10.5281/zenodo.1302956

Benito, Á., Yenisey, K. D., Khanna, K., Masis, M. F., Monge, R. M., Tugtan, M. A., Araya, L. D. V., \& Vig, R. (2021). Changes That Should Remain in Higher Education Post COVID-19: A Mixed-Methods Analysis of the Experiences at Three Universities. Higher Learning Research Communications, 11(0), 51-75. https://doi.org/10.18870/hlrc.v11i0.1195

Czerniewicz, L., Agherdien, N., Badenhorst, J., Belluigi, D., Chambers, T., Chili, M., de Villiers, M., Felix, A., Gachago, D., Gokhale, C., Ivala, E., Kramm, N., Madiba, M., Mistri, G., Mgqwashu, E., Pallitt, N., Prinsloo, P., Solomon, K., Strydom, S., ... Wissing, G. (2020). A Wake-Up Call: Equity, Inequality and Covid-19 Emergency Remote Teaching and Learning. Postdigital Science and Education, 2(3), 946-967. https://doi.org/10.1007/s42438-020-00187-4

Ewing, L. A., \& Cooper, H. B. (2021). Technology-enabled remote learning during COVID-19: perspectives of Australian teachers, students and parents. Technology, Pedagogy and Education, 30(1), 1-17. https://doi.org/10.1080/1475939X.2020.1868562

Ferri, F., Grifoni, P., \& Guzzo, T. (2020). Online Learning and Emergency Remote Teaching: Opportunities and Challenges in Emergency Situations. Societies, 10(86). https://doi.org/10.3390/soc10040086

Ghazi-Saidi, L., Criffield, A., Kracl, C. L., McKelvey, M., Obasi, S. N., \& Vu, P. (2020). Moving from Face-to-Face to Remote Instruction in a Higher Education Institution during a Pandemic: Multiple Case Studies. International Journal of Technology in Education and Science, 4(4), 370-383. https://doi.org/10.46328/ijtes.v4i4.169

Hodges, C., Moore, S., Lockee, B., Trust, T., \& Bond, A. (2020). The Difference Between Emergency Learning Remote Teaching and Online Learning. Educause Review, 1-15. https://er.educause.edu/articles/2020/3/the-difference-between-emergency-remote- 
Matarirano, O. et al. Students' Responses to Multi-Modal Emergency Remote Learning During COVID-19 in a South African Higher Institution

teaching-and-online-learning\%0Ahttps://er.educause.edu/articles/2020/3/the-

difference-between-emergency-remote-teaching-and-

Huang, M., Shi, Y., \& Yang, X. (2020). Emergency remote teaching of English as a foreign language during COVID-19: Perspectives from a university in China. IJERI: International Journal of Educational Research and Innovation, 15, 400-418.

https://doi.org/10.46661/ijeri.5351

Hurst, B., Wallace, R., \& Nixon, S. B. (2013). The impact of social interaction on student learning. Reading Horizons, 52(4), 375-398.

Idika, E. O. (2020). Students' and Teachers' Factors Hindering Effective Teaching and Learning of Economics in Secondary Schools in the Nsukka Local Government Area of Enugu State. Journal of Culture and Values in Education, 4(1), 49-63. https://doi.org/10.46303/jcve.2020.4

Ilonga, A., Ashipala, D. O., \& Tomas, N. (2020). Challenges experienced by students studying through open and distance learning at a higher education institution in namibia: Implications for strategic planning. International Journal of Higher Education, 9(4), 116-127. https://doi.org/10.5430/ijhe.v9n4p116

Jena, P. K. (2020). Challenges and Opportunities created by Covid-19 for ODL: A case study of IGNOU. International Journal for Innovative Research in Multidisciplinary Field, 6(5), 217-222. https://doi.org/10.31235/osf.io/jy2td

JISC. (2021). Student digital experience insights survey 2020/21: Findings from UK higher education and further education (pulse 1: October-December 2020). Online Learning and Distance Education Resources. https://www.tonybates.ca/2021/03/23/study-ofbritish-students-digital-experiences-during-the-covid-19-pandemic/

Kaisara, G., \& Bwalya, K. J. (2020). Investigating the E-Learning Challenges Faced by Students during Covid-19 in Namibia. International Journal of Higher Education, 10(1), 308. https://doi.org/10.5430/ijhe.v10n1p308

Kalimullina, O., Tarman, B. \& Stepanova, I. (2021). Education in the Context of Digitalization and Culture: Evolution of the Teacher's Role, Pre-pandemic Overview. Journal of Ethnic and Cultural Studies, 8(1), 226-238. DOI: http://dx.doi.org/10.29333/ejecs/629

Khalifeh, G., Noroozi, O., Farrokhnia, M., \& Talaee, E. (2020). Higher Education Students' Perceived Readiness for Computer-Supported Collaborative Learning. Multimodal Technologies and Interaction, 4(2), 11. https://doi.org/https://doi.org/10.3390/mti4020011

Krige, N. (2020). Survey reveals remote learning highs and lows.

https://www.news.uct.ac.za/article/-2020-08-05-survey-reveals-remote-learninghighs-and-lows

Krönke, M. (2020). Africa's digital divide and the promise of e-learning. In AFRO Barometer (Vol. 66).

https://www.researchgate.net/publication/342165040 Africa's digital divide and th e promise of e-learning

Makumane, M. A. (2021). Students' perceptions on the use of LMS at a Lesotho university amidst the COVID-19 pandemic. African Identities, 1-18.

https://doi.org/10.1080/14725843.2021.1898930 
Matarirano, O. et al. Students' Responses to Multi-Modal Emergency Remote Learning During COVID-19 in a South African Higher Institution

Mazana, M. Y. (2018). Social media in the classroom: WhatsApp a new communication tool for enhanced class interactions. Business Education Journal, 2(1), 1-8.

McCoy, C. (2010). Perceived self-efficacy and technology proficiency in undergraduate college students. Computers \& Education, 55, 1614-1617. https://doi.org/10.1016/j.compedu.2010.07.003

Mohmmed, A. O., Khidhir, B. A., Nazeer, A., \& Vijayan, V. J. (2020). Emergency remote teaching during Coronavirus pandemic: the current trend and future directive at Middle East College Oman. Innovative Infrastructure Solutions, 5(3). https://doi.org/10.1007/s41062-020-00326-7

Moore, M. G. (1989). Editorial: Three Types of Interaction. American Journal of Distance Education, 3(2), 1-7. https://doi.org/10.1080/08923648909526659

Naidoo, J. (2020). Postgraduate mathematics education students' experiences of using digital platforms for learning within the COVID-19 pandemic era. Pythagoras, 41(1). https://doi.org/10.4102/PYTHAGORAS.V4111.568

Nami, F., \& Vaezi, S. (2018). How ready are our students for technology-enhanced learning? Students at a university of technology respond. Journal of Computing in Higher Education, 30(3), 510-529. https://doi.org/10.1007/s12528-018-9181-5

Nayak, J. K., \& Singh, P. (2015). Fundamentals of Research Methodology: Problems and Prospects. In Fundamentals of Research Methodology. SSDN Publishers \& Distributors. https://doi.org/10.3926/oss.38em

Neff, L. S. (2021). Lev Vygotsky and Social Learning Theories. Educational Technology 547 Learning Theories Website. https://jan.ucc.nau.edu/Isn/educator/edtech/learningtheorieswebsite/vygotsky.htm

Nkomo, L. M., \& Daniel, B. K. (2021). Sentiment Analysis of Student Engagement with Lecture Recording. TechTrends, 65(2), 213-224. https://doi.org/10.1007/s11528-020-00563-8

O'Scanaill, M. (2020). Technology and Remote Learning: The Good, the Bad, and the Ugly. https://www.dyknow.com/blog/technology-and-remote-learning-the-good-the-badand-the-ugly/

Obuaku-Igwe, C. (2020). 'Umuntu ngumuntu ngabantu' (a person is a person because of other people): reflections on student's experiences of social isolation and the impact of a peer to peer mental health support group during covid-19 lockdown in South Africa. Youth Voice Journal, 2020(Special issue).

Okita, S. Y. (2012). Social interaction and learning. In N. M. Seel (Ed.), Encyclopedia of the Sciences of Learning (pp. 3104-3107). NY: Springer. https://doi.org/10.1007/978-14419-1428-6

Parker, S. W., Hansen, M. A., \& Bernadowski, C. (2021). Covid-19 campus closures in the united states: American student perceptions of forced transition to remote learning. Social Sciences, 10(62), 1-18. https://doi.org/10.3390/socsci10020062

Perry, N., Turner, J., \& Meyer, D. (2006). Classrooms as Contexts for Motivating Learning. In P. A. Alexander \& P. H. Winne (Eds.), Handbook of Educational Psychology (2nd ed., pp. 327-348). Lawrence Erlbaum. https://doi.org/10.4324/9780203874790.ch15

Pincock, K. (2020). Student Perspectives on Remote Learning. https://lumenlearning.com/student-perspectives-on-remote-learning/ 
Matarirano, O. et al. Students' Responses to Multi-Modal Emergency Remote Learning During COVID-19 in a South African Higher Institution

Prensky, M. (2001). Digital Natives, Digital Immigrants. MCB Press, 9(5). https://doi.org/https://doi.org/10.1108/10748120110424816

Rahiem, M. D. H. (2020). The emergency remote learning experience of university students in Indonesia amidst the COVID-19 crisis. International Journal of Learning, Teaching and Educational Research, 19(6), 1-26. https://doi.org/10.26803/ijlter.19.6.1

Rahn, M. (2021). Factor Analysis: A Short Introduction, Part 5-Dropping unimportant variables from your analysis. https://www.theanalysisfactor.com/factor-analysis5/\#: :text=As a rule of thumb,-off of \%7C0.7\%7C.

Rodriguez-Segura, L., Zamora-Antuñano, M. A., Rodríguez-Reséndiz, J., Paredes-García, W. J., Altamirano-Corro, J. A., \& Cruz-Pérez, M. Á. (2020). Teaching challenges in COVID-19 scenery: Teams platform-based student satisfaction approach. Sustainability, 12(18), 1-29. https://doi.org/10.3390/su12187514

Rossouw, M. (2018). The perceptions of students and lecturers on the live streaming of lectures as an alternative to attending class. South African Journal of Higher Education, 32(5), 253-269. https://doi.org/10.20853/32-5-2696

Sarosa, S. (2019). The Role of Brand Reputation and Perceived Enjoyment in Accepting Compulsory Device's s Usage : Extending UTAUT. Procedia Computer Science, 161, 115-122. https://doi.org/10.1016/j.procs.2019.11.106

Serhan, D. (2020). Transitioning from Face-to-Face to Remote Learning: Students' Attitudes and Perceptions of using Zoom during COVID-19 Pandemic. International Journal of Technology in Education and Science, 4(4), 335-342. https://doi.org/10.46328/ijtes.v4i4.148

Shim, T. E., \& Lee, S. Y. (2020). College students' experience of emergency remote teaching due to COVID-19. Children and Youth Services Review, 119. https://doi.org/10.1016/j.childyouth.2020.105578

Shin, M., \& Hickey, K. (2020). Needs a little TLC: examining college students' emergency remote teaching and learning experiences during COVID-19. Journal of Further and Higher Education, 1-14. https://doi.org/10.1080/0309877X.2020.1847261

Sokhulu, L. H. (2020). Students' experiences of using digital technologies to address their personal research needs during the COVID-19 lockdown. African Identities. https://doi.org/10.1080/14725843.2020.1801384

Songca, R. N., Ndebele, C., \& Mbodila, M. (2021). Mitigating the Implications of Covid - 19 on the Academic Project at Walter Sisulu University in South Africa: A Proposed Framework for Emergency Remote Teaching and Learning. Journal for Students Affairs in Africa, 9(1), 41-60. https://doi.org/10.24085/jsaa.v9i1.1427

South African Government News Agency. (2020). President Ramaphosa announces a nationwide lockdown. SA News.Gov.Za. https://www.sanews.gov.za/southafrica/president-ramaphosa-announces-nationwide-lockdown

Subedi, D., \& Subedi, R. (2020). Practicing Self Learning of ICT for Resilience Amidst the COVID-19 Outbreak: Experiences from Kathmandu Valley. Research in Educational Policy and Management, 2(2), 78-96. https://doi.org/10.46303/repam.2020.5

Vale, J., Oliver, M., \& Clemmer, R. M. C. (2020). The Influence of Attendance, Communication, and Distractions on the Student Learning Experience using Blended Synchronous 
Matarirano, O. et al. Students' Responses to Multi-Modal Emergency Remote Learning During COVID-19 in a South African Higher Institution

Learning. The Canadian Journal for the Scholarship of Teaching and Learning, 11(2). https://doi.org/10.5206/cjsotl-rcacea.2020.2.11105

Vygotsky, L. S. (1978). Mind in Society: The Development of Higher Psychological Processes (M. Cole, S. Scribner, V. John-Steiner, \& E. Souberman (eds.)). Harvard University Press. https://doi.org/10.2307/1421493

Wilcox, B. R., \& Vignal, M. (2020). Understanding the student experience with emergency remote teaching. 581-586. https://doi.org/10.1119/perc.2020.pr.wilcox

Williams, T. K., McIntosh, R. W., \& Russell, W. B. (2021). Equity in Distance Education During COVID-19. Research in Social Sciences and Technology, 6(1), 1-24. https://doi.org/10.46303/ressat.2021.1

Wise, A. F., \& Bergner, Y. (2020). College in the Time of Corona: Spring 2020 Student Survey. In NYU/LEARN.

Yuan, L. M. (2021). Student's Attitude and Satisfaction towards Transformative Learning: A Research Study on Emergency Remote Learning in Tertiary Education. Creative Education, 12(03), 494-528. https://doi.org/10.4236/ce.2021.123035

Yuhasriati, Jasmaniah, Azhari, B., Ma'Awiyah, A., Zulkifli, Syabuddin, Hamid, M., Hamidansyah, Ridhwan, M., Hambali, Ilyas, \& Bahri, S. (2020). E-Learning as Connector among Education Institution in the 4th Industrial Revolution. Journal of Physics: Conference Series, 1471(1), 8-13. https://doi.org/10.1088/1742-6596/1471/1/012024 